\title{
Comparison of Seismic Behaviour of Multi Storey Reinforced concrete Structure with Dual System
}

\author{
A. Md Mansoor Ahmed, A. Shaik Abdulla, A. Mohammed Riyan Ahmed
}

\begin{abstract}
In general, the structure can be prone to serious harm in elevated seismic regions. Along with the structure of the gravity load, the lateral load must be able to create elevated stresses. Now a days the shear wall in R.C structure with the steel structure and steel bracing system is most common for resisting lateral loads due to earthquake, wind, blast, etc. One of the finest lateral load resisting system is the shear wall. which is widely used in construction world. This study includes linear-static and non-linear static analysis of an E-shaped and diaphragm discontinuity G+ 14 multi-story RC building with different shear wall arrangements on dual system such as flat slab and shear wall, moment-resistant frames and shear wall using ETABS software for various irregular designs. Parameters like base shear, storey shear, storey drift, displacement.
\end{abstract}

Keywords- Dual System, Shear Wall, Flat Slab, Point Displacement, Storey Shear, Storey Drift, Diaphragm Discontinuity.

\section{INTRODUCTION}

At present in current areas there has been a huge increase in the construction of tall stories and their exceptional concern is about the existence of the structure that should be tall slender [1]. It is therefore critical that these buildings, together with vertical forces, resist horizontal forces. The structure should be addressed with these choices in terms of efficiency, as the buildings are big and slender are subjected to earth quake and wind loads. Because it is a mixture of two load resistant structures, dual system was considered to withstand lateral loads viably. Moment Resistant Frames (MRF) can be used as a dual structure with shear wall and flat slab with shear wall [2]. Shear walls are the most commonly used vertical structures that function as vertical cantilevers to sustainably withstand horizontal loads [3].

Manuscript revised on September 29, 2019 and published on October 10,2019

A. Md Mansoor Ahmed, Lecturer in Department of Civil Engineering at Khaja Banda Nawaz College of Engineering, Kalaburagi.

A. Shaik Abdulla, Lecturer in Department of Civil Engineering at Khaja Banda Nawaz College of Engineering, Kalaburagi.

A. Mohammed Riyan Ahmed, student of M.Tech (Structural Engineering) in Khaja Banda Nawaz College of Engineering, Kalaburagi.
In order to study the structure under breakdown, the efficiency and ductility features of a structure are mandatory. True dynamic analysis is usually not feasible and thus an assessment called pushover assessment is used in latest years that evaluates different parameters such as base shear, displacement, load drifts, etc [4].

In this study, a G+14 Store Reinforced Concrete (RC) buildi ng is analyzed by considering the effect of dual systemfor th is study, special moment resistant frames (SMRF) with shea $r$ wall and flat slab are considered as dual system

\section{METHODOLOGY}

A G+14 storey building measuring $30 \mathrm{~m} \times 25 \mathrm{~m}$ in plan having E shape with Shear Wall and Flat Slab is modeled in ETABS 2016. There are 5 models analysed in the present study by considering SMRF with shear wall and flat slab as dual system. Shear wall is used for E-shaped models at different locations.

\section{A. Description of Building Structure}

The details of the building is given in below Table 1

Table1. Description of Building Structure

\begin{tabular}{|c|c|}
\hline STRUCTURE & $\begin{array}{l}\text { DESCRIP } \\
\text { TION } \\
\end{array}$ \\
\hline No of Stories & $\mathrm{G}+14$ \\
\hline Height of one storey & $3 \mathrm{~m}$ \\
\hline Height of Base Storey & $3.5 \mathrm{~m}$ \\
\hline Soil Type & Medium Soil \\
\hline Seismic Zone & $\mathrm{V}$ \\
\hline Importance Factor & 1 \\
\hline Grade of Concrete & $\begin{array}{c}\text { M30 (Column) } \\
\text { M25 (Beam and Slab) }\end{array}$ \\
\hline Grade of Steel & $\mathrm{Fe} 415$ \\
\hline Size of the Beam & $300 \mathrm{mmX} 400 \mathrm{~mm}$ \\
\hline Size of the Column & $500 \mathrm{mmX} 500 \mathrm{~mm}$ \\
\hline Slab Thickness & $150 \mathrm{~mm}$ \\
\hline Live Load & $\begin{array}{r}2 \\
3 \mathrm{kN} / \mathrm{m} \\
\end{array}$ \\
\hline Live Load on Roof & $\begin{array}{c}2 \\
2.5 \mathrm{kN} / \mathrm{m} \\
\end{array}$ \\
\hline Floor Finish & $\begin{array}{r}2 \\
1 \mathrm{kN} / \mathrm{m} \\
\end{array}$ \\
\hline Column Drop & $300 \mathrm{~mm}$ \\
\hline
\end{tabular}




\section{E-ISSN: 2321-9637}

Available online at www.ijrat.org

\section{MODELING AND ANALYSIS}

For the current research, there are five models considered that include Shear Wall at various places. Models are conducted with equivalent static analysis and push over analysis. Different parameters like base shear, storey shear, storey drift, pushover curves are acquired based on the assessment. It reflects various kinds of models considered for the current research below from Fig1 toFig5.

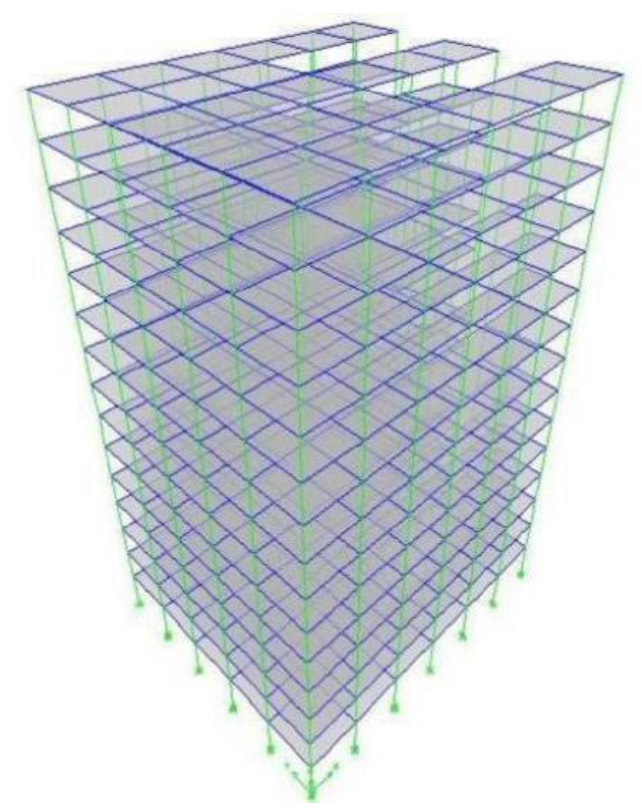

Figure 1. E-Shaped Bare Frame model

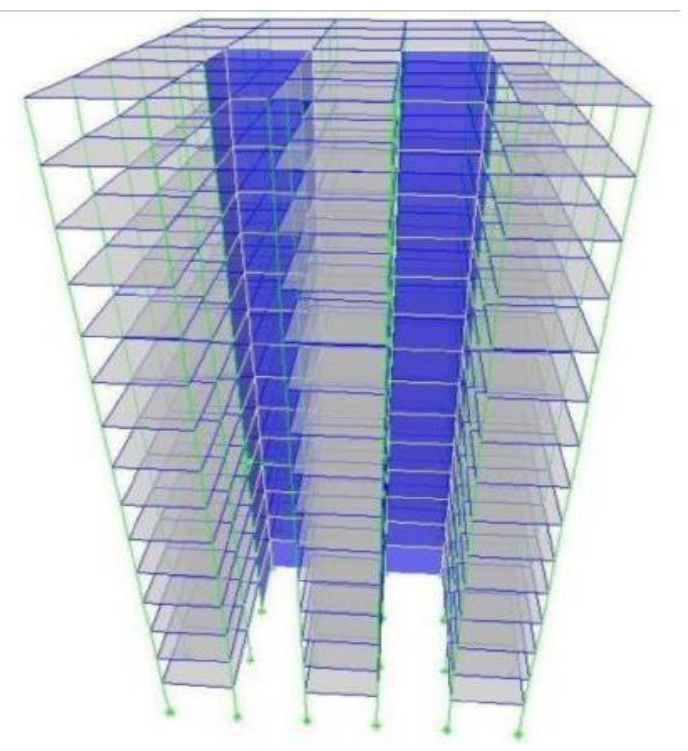

Figure 2. E- Shaped model with SMRF and shear wall at re-entrant corners.

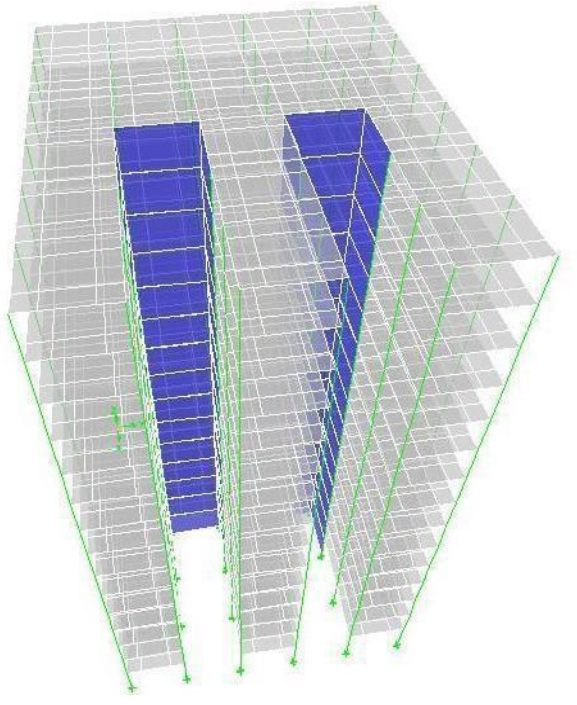

Figure 3. E- Shaped model with SMRF and shear wall at alternate periphery

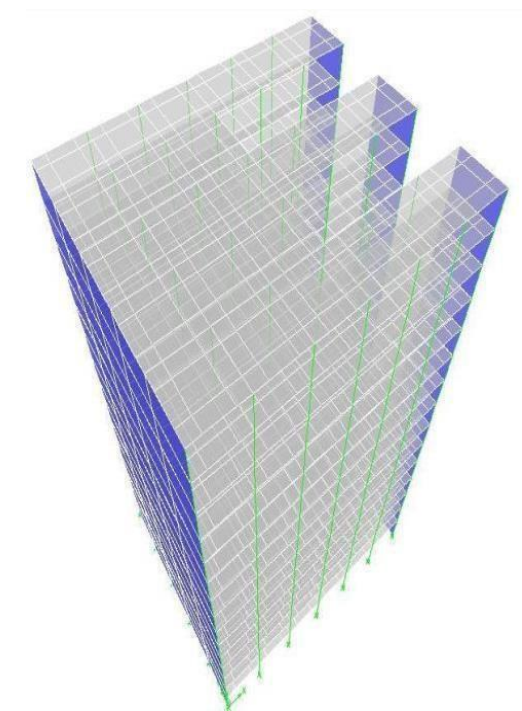

Figure 4. E-Shaped model with Flat Slab and Shear Wall at Re-Entrant Corners

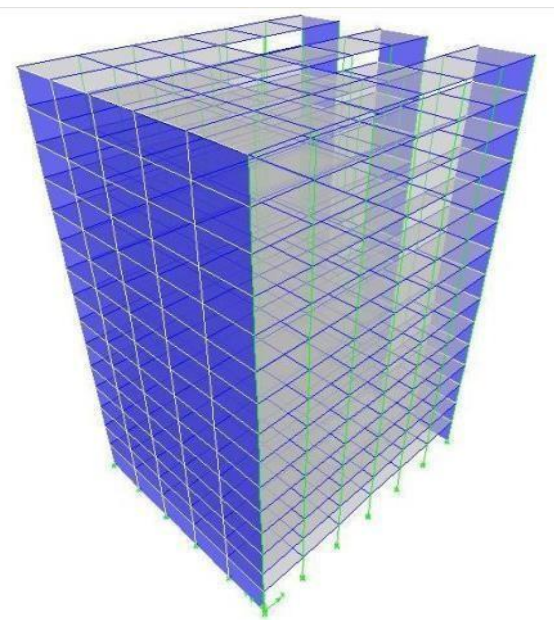

Figure 5. E-Shaped model with Flat Slab and Shear Wall at Alternate Periphery 
International Journal of Research in Advent Technology, Vol.7, No.9, September 2019

E-ISSN: 2321-9637

Available online at www.ijrat.org

\section{RESULTS}

The following results for linear static or equivalent static and non-linear static or pushover analysis are tabulated for both the considered models under various load combination as per IS 1893 Part-I 2002.

Here M1= E-Shaped Bare Frame Model

M2= E- Shaped model with SMRF and Shear Wall at re-entrant corners

M3= E- Shaped model with Flat slab and Shear Wall at re-entrant corners

M4= E-Shaped model with Flat Slab and Shear Wall at re-entrant corners

M5= E-Shaped model with Flat Slab and Shear Wall at alternate periphery

\section{A. BASE SHEAR}

\section{B. Table2. Base Shear in $\mathrm{kN}$}

\begin{tabular}{|l|l|l|l|l|}
\hline M1 & M2 & M3 & M4 & M5 \\
\hline 4805.26 & 5194.11 & 5323.72 & 4880.52 & 5038.8 \\
\hline
\end{tabular}

BASE SHEAR

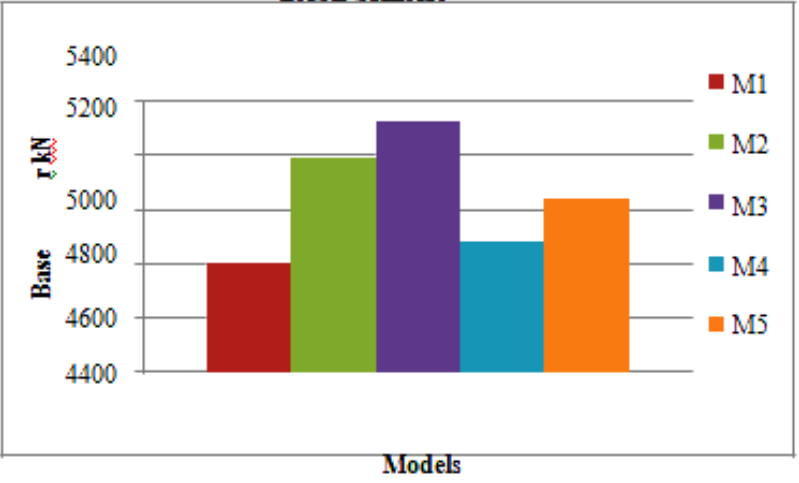

Figure 6. Base Shear for Model 1 to Model 5

\section{B. Storey Shear}

Table3. Base Shear for Model 1 to Model 5

\begin{tabular}{|c|c|c|c|c|c|}
\hline $\begin{array}{c}\text { Storey } \\
\text { No }\end{array}$ & M1 & M. & M3 & M4 & M5 \\
\hline 15 & 796.87 & 829.8 & 840.71 & 776.16 & 792.22 \\
\hline 14 & 1562.73 & 1663.65 & 1697.24 & 1560.34 & 1603.57 \\
\hline 13 & 2224.28 & 2383.94 & 2437.11 & 2237.73 & 2304.43 \\
\hline 12 & 2789.16 & 2998.97 & 3068.87 & 2816.12 & 2902.87 \\
\hline 11 & 3265 & 3517.05 & 3601.05 & 3303.35 & 3406.98 \\
\hline 10 & 3659.43 & 3946.5 & 4042.18 & 3707.22 & 3824.84 \\
\hline
\end{tabular}

\begin{tabular}{|l|c|c|c|c|c|}
\hline 9 & 3980.08 & 4295.63 & 4400.79 & 4035.55 & 4164.54 \\
\hline 8 & 4234.59 & 4572.73 & 4685.44 & 4296.15 & 4434.17 \\
\hline 7 & 4430.58 & 4786.13 & 4904.64 & 4496.83 & 4641.81 \\
\hline 6 & 4575.7 & 4944.13 & 5066.93 & 4645.42 & 4795.55 \\
\hline 5 & 4677.57 & 5055.04 & 5180.86 & 4749.73 & 4903.47 \\
\hline 4 & 4743.82 & 5127.17 & 5254.95 & 4817.56 & 4973.65 \\
\hline 3 & 4782.08 & 5168.83 & 5297.75 & 4856.74 & 5014.19 \\
\hline 2 & 4800 & 5188.34 & 5317.79 & 4875.09 & 5033.17 \\
\hline 1 & 4805.26 & 5194.11 & 5323.72 & 4880.52 & 5038.80 \\
\hline
\end{tabular}

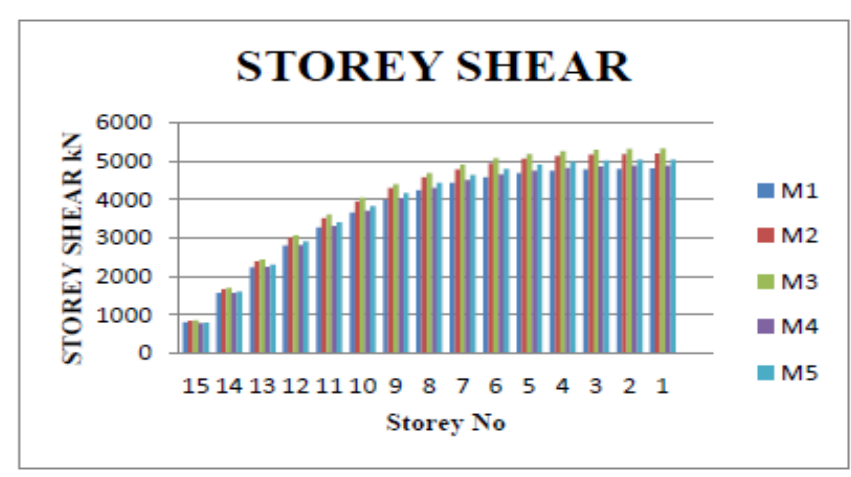

Figure 7. Storey Shear for Model 1 to Model 5

\section{Storey Drift}

Table4. Storey Drift for Model 1 to Model 5

\begin{tabular}{|c|c|c|c|c|c|}
\hline $\begin{array}{l}\text { Storey } \\
\text { No }\end{array}$ & Ml & $\mathrm{ND}$ & $\mathrm{MB}$ & M.4 & M.5 \\
\hline 15 & 0.001729 & 0.001307 & 0.001927 & 0.00106 & 0.001948 \\
\hline 14 & 0.002251 & 0.001372 & 0.001948 & 0.001121 & 0.001966 \\
\hline 13 & 0.002789 & 0.001422 & 0.001960 & 0.00117 & 0.001975 \\
\hline 12 & 0.003267 & 0.001469 & 0.001964 & 0.001217 & 0.001974 \\
\hline 11 & 0.00367 & 0.001503 & 0.001952 & 0.001255 & 0.001958 \\
\hline 10 & 0.003995 & 0.001522 & 0.001922 & 0.001279 & 0.001923 \\
\hline 9 & 0.004246 & 0.00152 & 0.001869 & 0.001286 & 0.001865 \\
\hline 8 & 0.004429 & 0.001495 & 0.001789 & 0.001272 & 0.001781 \\
\hline 7 & 0.004549 & 0.001443 & 0.001681 & 0.001235 & 0.001669 \\
\hline 6 & 0.00461 & 0.001363 & 0.001541 & 0.001173 & 0.001525 \\
\hline 5 & 0.004616 & 0.00125 & 0.001367 & 0.001081 & 0.00135 \\
\hline 4 & 0.004556 & 0.001101 & $0.00115 ?$ & 0.000958 & 0.00114 \\
\hline 3 & 0.004386 & 0.000911 & 0.00091 & 0.000797 & 0.000893 \\
\hline 2 & 0.003932 & 0.000673 & 0.000623 & 0.000592 & 0.000609 \\
\hline 1 & 0.002382 & 0.000329 & 0.000261 & 0.0003 & 0.000253 \\
\hline
\end{tabular}




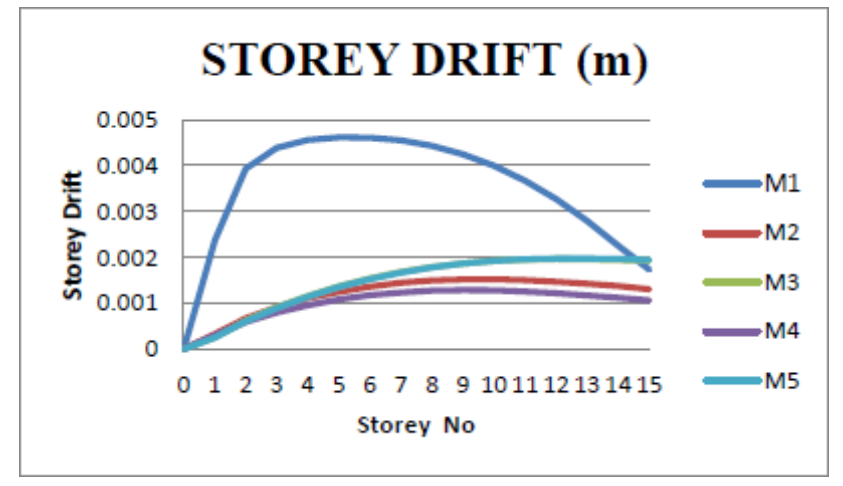

Figure 8. Storey Drift for Model 1 to Model 5

\section{Pushover Curves}

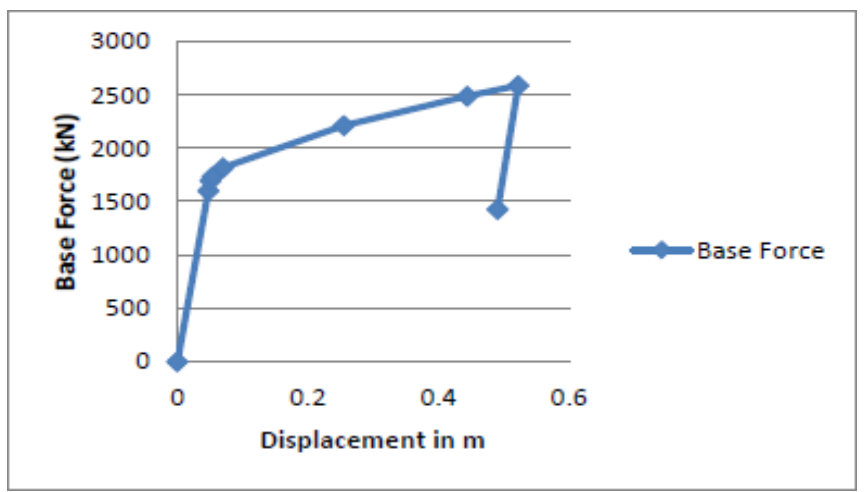

Figure 9. Pushover Curve for Model M1

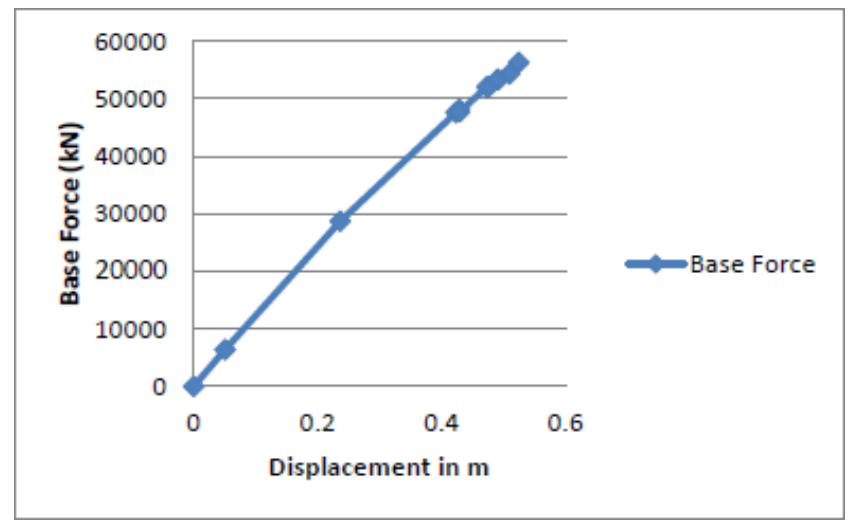

Figure 10. Pushover Curve for Model M2

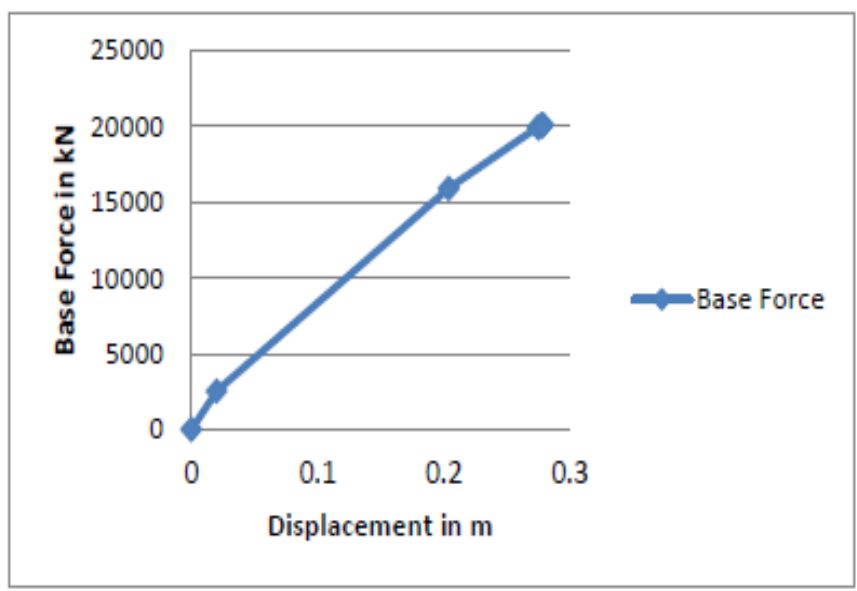

Figure 11. Pushover Curve for Model M3

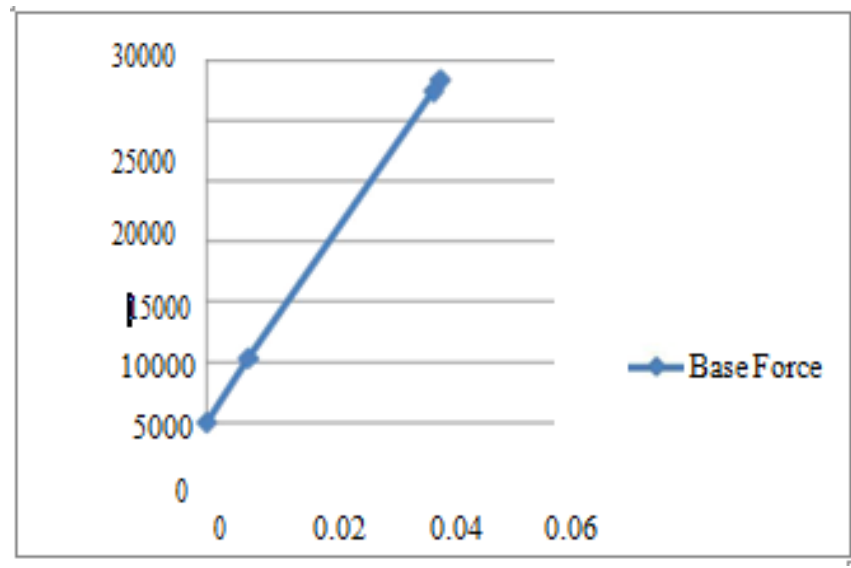

Figure 12. Pushover Curve for Model M4

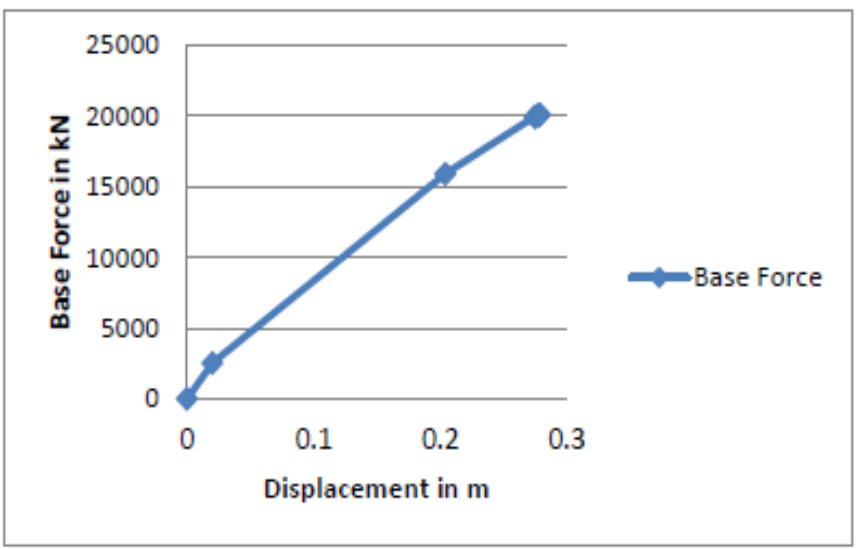

Figure 13. Pushover Curve for Model M5

\section{CONCLUSION}

1. In E shaped model the base shears and storey shears is found to be highest for flat slab and shear wall at re-entrant corners dual system when compared to all the other E shaped models.

2. Storey Drift is found minimum in E-Shaped model with flat slab and shear wall combination.

3. From the graphs plotted it is clearly seen that the bare frame for model $\mathrm{E}$ is the most vulnerable model in the seismic zone $\mathrm{V}$ owing to the absence of lateral load resisting system.

4. The post-yield behavior for overall performance level for the $\mathrm{G}+14$ storey $\mathrm{RC}$ framed building with various systems considered in this study are found to lie within the life safety range (i-e., LS - CP).

\section{REFERENCES}

[1] Md Zibran Pawaar (2015) 'Performance Based Seismic Analysis of Rc Building Considering the Effect of Dual Systems', IJRET: International Journal of Research in Engineering and Technology eISSN: 2319-1163.

[2] Neethu Padayattil, Sajitha R Nair (2016). "Study on Seismic Behavior of Dual System in High Seismic Zone," International Journal of Scientific \& Engineering Research, Volume 7, Issue 10, October-2016.

[3] Emre Karamanci, Dimitrios G. Lignos, A.M.ASCE, (2014). "Computational Approach for Collapse Assessment of Concentrically Braced Frames in Seismic Regions," J. Struct. Engrg. 140(8): A4014019. 
International Journal of Research in Advent Technology, Vol.7, No.9, September 2019

E-ISSN: 2321-9637

Available online at www.ijrat.org

[4] Hamdy Abou Elfath, Mostafa Ramadan, Fozeya Omar Alkanai, (2017). "Upgrading the seismic capacity of existing RC buildings using buckling restrained braces," Alexandria Engineering Journal $56,251-262$

\section{AUTHORS PROFILE}

Mohammed Mansoor Ahmed working as Lecturer in Department of Civil Engineering at Khaja Banda Nawaz College of Engineering, Kalaburagi. He published 16 International journals. $\mathrm{He}$ attended 36 national

Shaik Abdulla working as Lecturer in Department of Civil Engineering at Khaja Banda Nawaz College of Engineering, Kalaburagi. He presented research paper life assessment and extension of RCC framed building subjected to Fatigue Loading Analytical Approach at Fatigue Durability India 2019 held at VTU Belagavi. He published 36 International journals.

Mohammed Riyan Ahmed is a student of M.Tech (Structural Engineering) in Khaja Banda Nawaz College of Engineering, Kalaburagi. 